\title{
Prevalence and risk factors associated with common mental disorders among medical students
}

\section{Prevalência e fatores de risco associados a transtornos mentais comuns entre os estudantes de medicina}

\section{Prevalencia y factores de riesgo asociados a transtornos mentales comunes entre los estudiantes de medicina}

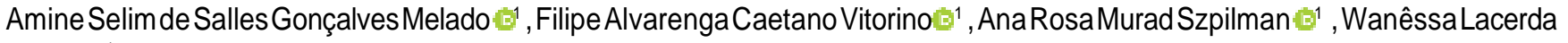
Poton 1

${ }^{1}$ Universidade Vila Velha (UVV). Vila Velha, ES, Brasil.

\begin{abstract}
Objective: To identify the prevalence of common mental disorders (CMD) in medical students at Vila Velha University (UVV), ES, and its associated factors. Methods: A cross-sectional study was conducted with 360 medical students from February to April 2018. A self-administered, confidential and online questionnaire was used, including sociodemographic, economic data, family support, friends' network, physical activity and academic performance, as well as SelfReporting Questionnaire (SRQ-20). Statistical analysis was performed using the STATA program, version 13.0. The Ethics Committee on Research with Humans approved the study, under number 2.108.290. Results: The prevalence of CMD among students was $45.6 \%$. Risk factors were mental disorder in the family (RR $1.24,95 \% \mathrm{Cl} 1.01-1.54$ ), poor sleep quality (RR $1.49,95 \%$ $\mathrm{Cl} 1.17-1.90$ ), fear that impaired the academic result (RR 1.33, 95\% Cl 1.01-1.77), feeling rejected by friends (RR 1.45, 95\% $\mathrm{Cl} 1.07-1.96)$, thinking about giving up the course (RR 1.67, $95 \% \mathrm{Cl} 1.29-2.17$ ) and physical discomfort during the test (RR 1.63, 95\% Cl, 1.21-2.20). Conclusions: The overall prevalence of CMD among students was high, and the risk factors were significant. It is recommended that educational institutions and responsible government agencies be able to formulate and subsidize preventive actions and care for the mental health of medical students.
\end{abstract}

Keywords: Students, Medical; Mental Disorders; Epidemiology; Risk Factors

Cite as: Melado ASSG, Vitorino FAC, Szpilman ARM, Poton WL. Prevalência e fatores de risco associados a transtornos mentais comuns entre os estudantes de medicina. Rev Bras Med Fam Comunidade. 2019;14(41):1911. https://doi.org/10.5712/rbmfc14(41)1911
Corresponding author:

Amine Selim de Salles Gonçalves Melado. Email: aminesalles@gmail.com

Funding:

none declared.

Ethical approval:

2.108.290 (UVV), approved on 06/08/2017

Provenance and peer review: peer reviewed.

Received: 11/04/2018.

Accepted: 08/27/2019. 


\section{Resumo}

Objetivo: Identificar a prevalência de transtornos mentais comuns (TMC) nos estudantes de medicina da Universidade Vila Velha (UVV), ES, e seus fatores associados. Métodos: Estudo transversal com 360 estudantes de medicina, de fevereiro a abril de 2018. Utilizou-se um questionário autoaplicável, confidencial e online, incluindo dados sociodemográficos, econômicos, suporte familiar, rede de amigos, atividade física e desempenho acadêmico, assim como o teste Self-Reporting Questionnaire (SRQ-20). A análise estatística foi realizada utilizando-se do programa STATA, versão 13.0. O Comitê de Ética em Pesquisa com Seres Humanos aprovou o estudo, sob o número 2.108.290. Resultados: A prevalência de TMC entre os estudantes foi de 45,6\%. Os fatores de risco foram transtorno mental na família (RR 1,24; IC95\% 1,01-1,54), qualidade do sono insatisfatória (RR 1,49; IC95\% 1,17-1,90), medo que prejudica o rendimento escolar (RR 1,33; IC95\% 1,01-1,77), sentir-se rejeitado pelos amigos (RR 1,45; IC95\% 1,07-1,96), pensar em desistir do curso (RR 1,67; IC95\% 1,29-2,17) e desconforto físico durante a prova (RR 1,63; IC95\% 1,21-2,20). Conclusões: A prevalência geral de TMC entre os estudantes foi alta, e os fatores de risco foram expressivos. Recomenda-se que as instituições de ensino e órgãos governamentais responsáveis possam formular e subsidiar ações preventivas e um cuidado à saúde mental dos estudantes de medicina.

Palavras-chave: Estudantes de Medicina; Transtornos Mentais; Epidemiologia; Fatores de Risco

\section{Resumen}

Objetivo: Identificar la prevalencia de trastornos mentales comunes (TMC) en los estudiantes de medicina de la Universidad Vila Velha (UVV), ES, y sus factores asociados. Métodos: Estudio transversal con 360 estudiantes de medicina, de febrero a abril de 2018. Se utilizó un cuestionario autoaplicable, confidencial y online, incluyendo datos sociodemográficos, económicos, soporte familiar, red de amigos, actividad física y desempeño académico, así como el examen Self-Reporting Questionnaire (SRQ-20). El análisis estadístico se realizó utilizando el programa STATA, versión 13.0. El Comité de Ética en Investigación con Seres Humanos aprobó el estudio, bajo el número 2.108.290. Resultados: La prevalencia de TMC entre los estudiantes fue del 45,6\%. Los factores de riesgo fueron trastorno mental en la familia (RR 1,24 IC95\% 1,01-1,54), calidad del sueño insatisfactoria (RR 1,49, IC95\% 1,17-1,90), miedo que perjudica el rendimiento escolar (RR 1,33, IC95\% $1,01-1,77$ ), sentirse rechazado por los amigos (RR 1,45, IC95\% 1,07-1,96), pensar en desistir del curso (RR (IC95\% 1,29-2,17) y la incomodidad física durante la prueba (RR 1,63, IC95\% 1,21-2,20). Conclusiones: La prevalencia general de TMC entre los estudiantes fue alta, y los factores de riesgo fueron expresivos. Se recomienda que las instituciones de enseñanza y órganos gubernamentales responsables puedan formular y subsidiar acciones preventivas y un cuidado a la salud mental de los estudiantes de medicina.

Palabras clave: Estudiantes de Medicina; Trastornos Mentales; Epidemiología; Factores de Riesgo

\section{Introduction}

Scientific investigations have been identifying a high prevalence of psychiatric symptoms and Common Mental Disorders (CMD) among medical students, mainly associated with academic excess. ${ }^{1,2}$ The stressed medical university environment, many times, harms the student's academic performance in their physical health and psychosocial well-being, affecting their quality of life. ${ }^{3}$

CMD is a syndrome characterized by depressive and anxiety symptoms, irritability, fatigue, insomnia, memory, and concentration difficulty, ${ }^{1,4-6}$ which can manifest as a mixture of somatic symptoms, ${ }^{5,6}$ like tremors, headache, poor digestion, among others. ${ }^{6}$

The study performed with Gondar University Students in Ethiopia found a CMD prevalence of $40.9 \% .{ }^{7}$ Another study with students from a public university in a Brazilian South region found $51.5 \%{ }^{8}$ and in a Brazilian Southeast region found $31.7 \% .{ }^{1}$ Studies in the scientific literature show that the prevalence of $\mathrm{CMD}$ is higher among medical students than the general population, as they are subject to a higher potential, such as failure of the network of friends, knowledge overload, problem selection, individualism, social responsibilities and absences from the role of doctor, contact with death and pathological processes, physical exercise of patients, fear of getting sick, fear of making mistakes and feelings of helplessness in the face of certain illnesses, lack of religious practice, financial problems, family history of mental disorders, drug 
use, and poor academic outcomes. These factors can lead students to psychological defense mechanisms such as dissociation or isolation. ${ }^{1,2,4,7}$

The knowledge of associated factors to CMD among medical students becomes essential so that the educational institution can carry out institutional strategies to improve the students' quality of life and even make it reflect on the current curriculum model. Therefore, this study aimed to estimate the CMD prevalence and associated factors in a private university among medical students.

\section{Methods}

The transversal study performed with first to sixth year Vila Velha University (UVV) medical students, from February to April 2018. The UVV is a private university located in Vila Velha, a municipality in the Metropolitan Region of Espírito Santo State. In 2007 the Medical School was implanted, has a duration of six years with integral dedication, and uses the Problem Based Learning (PBL) as a learning methodology. The regular registration in Vila Velha University (UVV) is a requirement to participate in this study, which represented approximately 780 medical students. All students were invited to participate in the research by disclosing the invitation to the announcement wall in the academic blog and the classroom.

The sample size was calculated using Stata statistical program, presuming a population of 780 , a confidence level of $95 \%$, a random error of $20 \%$, and CMD prevalence of $51.5 \%,{ }^{8}$ estimating a sample of 258 students.

The information was obtained using a structured online, self-applicable, and confidential questionnaire, divided into five sections. The first section contains students' sociodemographic characteristics. The second section has information about the students' relationship with their relatives. The third section investigates the teaching-learning process, the performance, and satisfaction with the course. The fourth section contains information about students and their relatives' mental health follow-up. Lastly, the fifth section is the Self-Reporting Questionnaire (SRQ-20).9,10

The SRQ-20 was used in this study to estimate the students' CMD prevalence. This standardized instrument was created by the World Health Organization (WHO) to psychiatric disturbs' screening in Primary Health Care services, and it was validated in Brazil by Mari and Williams. ${ }^{11}$ The SRQ-20 has 20 questions with yes and no answers, being four about physical symptoms and 16 about psycho-emotional disorders. The symptoms analyzed refer to the last 30 days and for each affirmative answer, it is attributed to one point, resulting in a final score that varies from 0 to 20 points. The students were distributed in two groups accordingly to their punctuation in SRQ-20, being the cut-off point different for men and women. Men with punctuation lower than or equal to five and women with punctuation lower than or equal to seven were classified as "not suspected to CMD." Men with punctuation greater than or equal to six and women with punctuation greater than or equal to eight were classified as "suspected to CMD".

The questionnaire was applied in order to evaluate the information quality before the beginning of the study to 10 students enrolled in other UVV graduation courses and some modifications in the instrument were made. Since it is an online fulfilled questionnaire, as soon as the student submits their answers, the information was automatically inserted in a spreadsheet in Excel 2010, which eliminated the incompleteness answer problem. 
The statistical analyses were performed using STATA, version 13.0. We described continuous variables as means +- standard, and categorical variables as counts and percentages in tables' data presentation of the total and partial sample. A Poisson regression model with robust variance estimation was used to identify the CMD associated factors among medical students that never had psychiatric and/or psychological treatment. The exclusion of students with previous psychiatric and/or psychological treatment $(n=42)$ was because the study aimed to identify only the influencing factors on the behavior's student after they were enrolled in the university medical course. The regression model was adjusted to control confounding variables, and, before entered in the model, the variables that presented independent association to CMD were identified when presented $p$-value $<0.05$. The variables entered in the multiple regression model using the Backward Stepwise method to evaluate the variables that presented CMD independent association and considered the ones who finished the model with $p$-value $<0.05$. Tests were used to evaluate the model-adjusted quality. It was used a hierarchical model organized in levels. The first level included the variables related to the student and his family that was "sex," "a mental disorder in the family," "students' chronic and physical disease," and "physical activity practice." In the second level were the variables related to the students' relationship with friends and family, and how they feel in the university, that included "difficulty to make friends", "friends' emotional support", "feel rejected by friends", "parents' emotional support", "relationship difficulty with parents", "liberty to talk to their parents", "difficulty to clarify doubts in the classroom", "fear that compromises the academic performance", "sleeping difficulty", "sleeping quality", "physical discomfort during exams", and "difficulty to balance study and leisure". On the third level was included the variables about their satisfaction and performance with the course, which were "thought about giving up the course", "course level of satisfaction", "classes dynamic", "satisfaction with the grades", and "academicperform".

The UVV Research Ethics Committee, under the number 2.108.290, approved the research on June $8^{\text {th }}$ 2017. The students were informed about the research and electronically consented their participation before answered the online questionnaire.

\section{Results}

From 398 students who answered the questionnaire, 38 students were in psychiatric and/or psychological treatment before enrolling in the Medical course in the university.

The majority interviewed was female, white and single. The age average was 21 years and the majority was enrolled in the first two years of the course. The vast majority presented their expenses sponsored by their family and, approximately a fourth of them had a relative with a mental disorder. Many did not practice any physical activity and 39 (10.8\%) informed having a chronical physical disease. There was no difference between total and partial sample (Table 1).

The SRQ-20 mean score was 7.0 (SD 4.4) in the total sample and 6.6 (SD 4.2) in the partial sample, varying from 0 to 20 (Table 1 ).

The participants' emotional characteristics are presented in table 2. Many students reported sleeping difficulties; in a little more than half the sleep quality was poor; besides that, almost two-thirds do not achieve study and leisure balance. Some described difficulty in making friends, more than half feel rejected, and 4.5\% (total sample) and 3.6\% (partial sample) do not have friends' emotional support. About their relationship with their parents, the majority referred has parents' emotional support; however, just over a third have 
Table 1. The participants' sociodemographic and health characteristics and family mental health, Vila Velha University-ES, Brazil, 2018.

\begin{tabular}{|c|c|c|c|}
\hline Variables & $\begin{array}{l}\text { Total sample } \\
\qquad(n=402) \\
n(\%)\end{array}$ & $\begin{array}{c}\text { Partial } \\
\text { samplea }^{a}(n= \\
360) \\
n(\%)\end{array}$ & $\begin{array}{c}p \\
\text { value }\end{array}$ \\
\hline $\mathrm{Age}^{\mathrm{C}}$ & $21.8(3.5)$ & $21.9(3.6)$ & \\
\hline Sex & & & 0.586 \\
\hline Male & $152(37.8)$ & $144(40.0)$ & \\
\hline Female & $250(62.2)$ & $216(60.0)$ & \\
\hline \multicolumn{4}{|l|}{ Skin Color } \\
\hline White & $289(71.9)$ & $253(70.3)$ & 0.681 \\
\hline Not white & $113(28.1)$ & $107(29.7)$ & \\
\hline Age (years) & & & 0.970 \\
\hline$<19$ & $100(24.9)$ & 87 (24.2) & \\
\hline $20-24$ & $238(59.2)$ & $216(60.0)$ & \\
\hline $25+$ & $64(15.9)$ & $57(15.8)$ & \\
\hline Marital Status & & & 0.973 \\
\hline Single & $381(94.8)$ & $341(94.7)$ & \\
\hline Married/stable union & $21(5.2)$ & $19(5.3)$ & \\
\hline Course Period (Year) & & & 0.998 \\
\hline $1^{\circ}$ & $117(29.1)$ & $101(28.1)$ & \\
\hline $2^{0}$ & $147(36.6)$ & $133(36.9)$ & \\
\hline $3^{\circ}$ & $31(7.7)$ & $27(7.5)$ & \\
\hline $4^{\circ}$ & $55(13.7)$ & $51(14.2)$ & \\
\hline $5^{\circ}$ & $30(7.5)$ & $26(7.2)$ & \\
\hline $6^{0}$ & $22(5.5)$ & $22(6.1)$ & \\
\hline Students' Mental Disorders - SRQ & $7.0(4.4)^{\mathrm{C}}$ & $6.6(4.2)^{\mathrm{C}}$ & 0.342 \\
\hline Suspect & $199(49.3)$ & $164(45.6)$ & \\
\hline Non suspect & $205(50.7)$ & $196(54.4)$ & \\
\hline Students' Chronic Physical Disease & & & 0.325 \\
\hline Yes & $54(13.4)$ & $39(10.8)$ & \\
\hline No & $348(86.6)$ & $321(89.2)$ & \\
\hline Physical Activity Practice & & & 0.650 \\
\hline Yes & $237(59.0)$ & $219(60.8)$ & \\
\hline No & $165(41.0)$ & $141(39.2)$ & \\
\hline Mental Disorder in the family & & & 0.799 \\
\hline Yes & $101(25.1)$ & $83(23.0)$ & \\
\hline No & $270(67.2)$ & $249(69.2)$ & \\
\hline Do not know & $31(7.7)$ & $28(7.8)$ & \\
\hline
\end{tabular}

${ }^{a}$ Partial sample within the adolescents with psychiatric and/or psychological treatment prior; ${ }^{b}$ Chi-square heterogeneity test; ${ }^{\circ}$ Average and standard deviation (SD).

relationship difficulty and do not have the liberty to talk to their parents about many subjects. Some also presented difficulties in the classroom, where over half referred no achievement on clarifying their doubts in the classroom. Just over two-fifths stated that the fear compromises their academic performance and over half presented physical discomfort during the exams. There was no difference between the samples (Table 2). 
Table 2. Analyzed participants' emotional characteristics, Vila Velha University-ES, Brazil, 2018.

\begin{tabular}{|c|c|c|c|}
\hline Variables & $\begin{array}{l}\text { Total sample } \\
\qquad \begin{array}{c}(n=398) \\
n(\%)\end{array}\end{array}$ & $\begin{array}{c}\text { Partial } \\
\text { sample }^{a}(n= \\
360) \\
n(\%)\end{array}$ & $\stackrel{p}{\text { value }^{b}}$ \\
\hline Yes & $84(20.9)$ & $67(18.6)$ & \\
\hline Sometimes & $59(14.7)$ & $50(13.9)$ & \\
\hline Satisfatctory & $172(42.8)$ & $162(45.0)$ & \\
\hline Unsatisfactory & $230(57.2)$ & $198(55.0)$ & \\
\hline Difficulty to balance study and leisure & & & 0.979 \\
\hline Yes & $162(40.3)$ & $143(39.7)$ & \\
\hline Sometimes & $123(30.6)$ & $102(28.3)$ & \\
\hline No & $243(60.4)$ & $228(63.3)$ & \\
\hline Friends' emotional support & & & 0.619 \\
\hline Yes & $301(74.9)$ & $280(77.8)$ & \\
\hline Sometimes & $83(20.6)$ & $67(18.6)$ & \\
\hline No & $18(4.5)$ & $13(3.6)$ & \\
\hline Feel rejected by friends & & & 0.641 \\
\hline Yes & $182(45.3)$ & $153(42.5)$ & \\
\hline No & $152(37.8)$ & $148(41.1)$ & \\
\hline Sometimes & $61(15.2)$ & $56(15.6)$ & \\
\hline No & $277(68.9)$ & $252(70.0)$ & \\
\hline Liberty to talk to their parents & & & 0.995 \\
\hline Yes & $142(35.3)$ & $127(35.3)$ & \\
\hline Sometimes & $116(28.9)$ & $105(29.2)$ & \\
\hline No & $144(35.8)$ & $128(35.6)$ & \\
\hline Difficulty to clarify doubts in the classroom & & & 0.897 \\
\hline Yes & $138(34.3)$ & $118(32.8)$ & \\
\hline Sometimes & $86(21.4)$ & $80(22.2)$ & \\
\hline No & $178(44.3)$ & $162(45.0)$ & \\
\hline Fear that compromises the academic performance & & & 0.509 \\
\hline Yes & $107(26.6)$ & $84(23.3)$ & \\
\hline Sometimes & $65(16.2)$ & $56(15.6)$ & \\
\hline No & $230(57.2)$ & $220(61.1)$ & \\
\hline Physical discomfort during exams & & & 0.748 \\
\hline Yes & $147(36.6)$ & $123(34.2)$ & \\
\hline Sometimes & $72(17.9)$ & $70(19.4)$ & \\
\hline No & $183(45.5)$ & $167(46.4)$ & \\
\hline
\end{tabular}

a Partial sample within the adolescents with psychiatric and/or psychological treatment prior; ${ }^{\mathrm{b}} \mathrm{Chi}$-square heterogeneity test. 
Concerning their feelings towards the medical course, despite one third have thought at some point to give up the course, few are not satisfied with the course and, part of the dissatisfaction is related to the class dynamic. Nevertheless, more than half are satisfied with their grades and their academic achievement. A statistically significant difference between the samples was not found (Table 3).

Table 3. Participants' vision on information about the course, Vila Velha University-ES, Brazil, 2018.

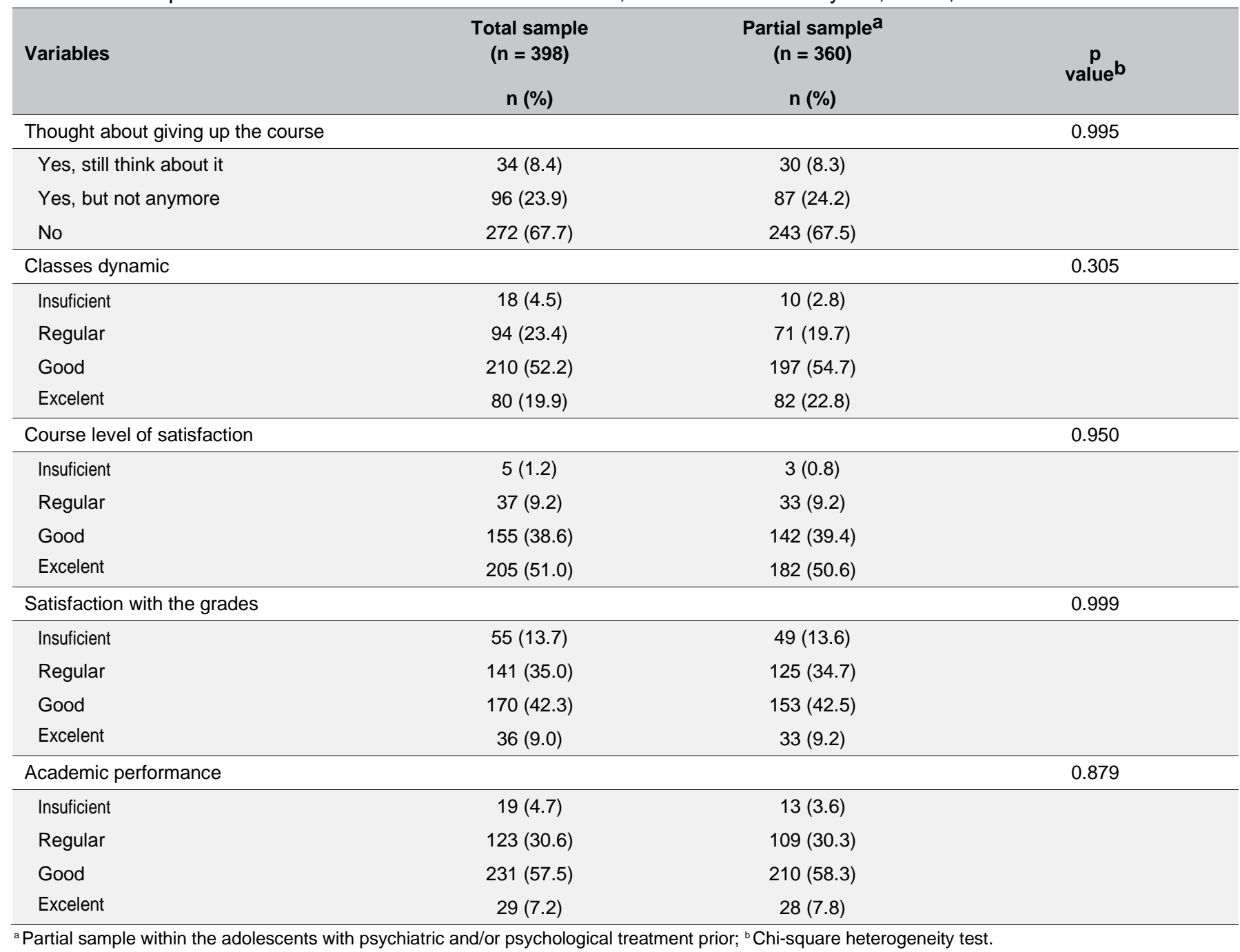

The CMD medical students' associated factors were mental disorder present in the family (RR 1.24; $95 \% \mathrm{Cl} 1.01,1.54)$, unsatisfactory sleep quality (RR 1.49; $95 \% \mathrm{Cl} 1.17,1.90)$, fear that compromises the academic performance ( $R R$ 1.33; 95\% Cl 1.01, 1.77), feel rejected by friends ( $R R 1.45 ; 95 \% \mathrm{Cl} 1.07,1.96)$, thought about giving up the course (RR 1.67; 95\% $\mathrm{Cl} 1.29,2.17)$, as well as physical discomfort during the exams (RR 1.63; 95\% Cl 1.21, 2.20) (Table 4).

\section{Discussion}

In this present study, the CMD prevalence among medical students was $45.6 \%$. This prevalence resembles the one found in the Netherlands (48.0\%) ${ }^{12}$ and in Ethiopia (40.9\%). In Island (22.5\%), ${ }^{13}$ Australia $(19.2 \%),{ }^{14}$ as well as in Espírito Santo University (37.1\%), ${ }^{1}$ the prevalence was lower than in this study. 
Table 4. Brute and adjusted analysis of the associated factors of the medical students' mental disorders without previous psychological and/or psychiatric treatment in Vila Velha University-ES, Brazil, $2018(n=360)$.

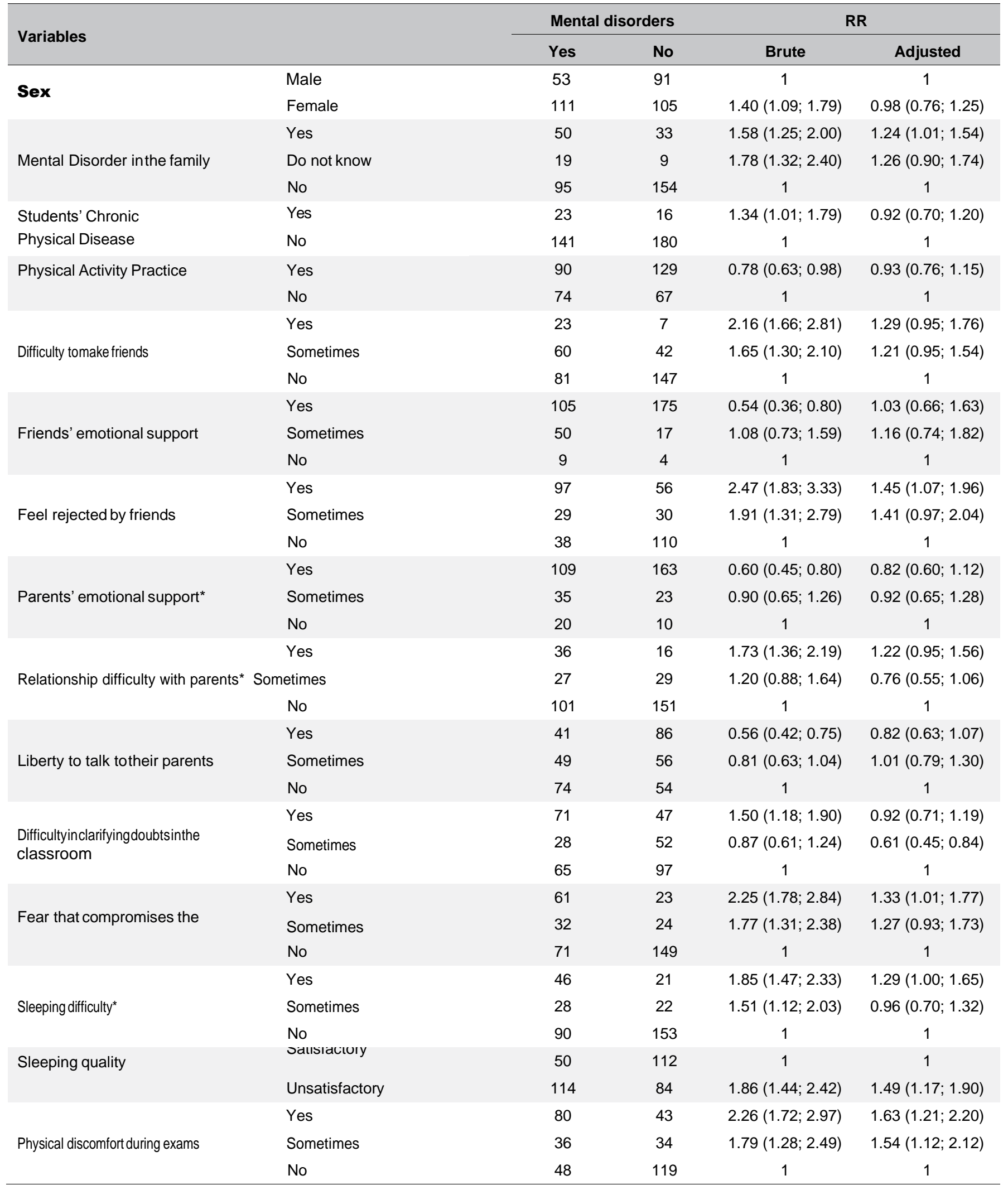


Continuation Table 4.

\begin{tabular}{|c|c|c|c|c|c|}
\hline \multirow{2}{*}{ Variables } & & \multicolumn{2}{|c|}{ Mental disorders } & \multicolumn{2}{|c|}{$\mathbf{R R}$} \\
\hline & & Yes & No & Brute & Adjusted \\
\hline \multirow{3}{*}{$\begin{array}{l}\text { Difficulty tobalance studyand } \\
\text { leisure* }^{\star}\end{array}$} & Yes & 90 & 53 & $2.14(1.60 ; 2.86)$ & $1.53(1.14 ; 2.06)$ \\
\hline & Sometimes & 34 & 47 & $1.43(0.99 ; 2.06)$ & $1.09(0.76 ; 1.54)$ \\
\hline & No & 40 & 96 & 1 & 1 \\
\hline \multirow{3}{*}{$\begin{array}{l}\text { I nought about giving up the } \\
\text { course }\end{array}$} & Yes, still think & 25 & 5 & $2.27(1.81 ; 2.86)$ & $1.67(1.29 ; 2.17)$ \\
\hline & Yes, but do not thinkanymore & 50 & 37 & $1.57(1.23 ; 2.00)$ & $1.30(1.02 ; 1.65)$ \\
\hline & No & 89 & 154 & 1 & 1 \\
\hline \multirow{4}{*}{$\begin{array}{l}\text { Level of satisfaction with the } \\
\text { course }\end{array}$} & Insufficient & 3 & 0 & 1 & 1 \\
\hline & Regular & 22 & 11 & $0.67(0.52 ; 0.85)$ & $1.20(0.78 ; 1.84)$ \\
\hline & Good & 70 & 72 & $0.49(0.42 ; 0.58)$ & $1.06(0.71 ; 1.58)$ \\
\hline & Excellent & 69 & 113 & $0.38(0.1 ; 0.46)$ & $0.89(0.58 ; 1.36)$ \\
\hline \multirow{4}{*}{ Classes dynamic ${ }^{\star}$} & Insuficient & 12 & 3 & 1 & 1 \\
\hline & Regular & 44 & 39 & $0.66(0.48 ; 0.92)$ & $1.10(0.71 ; 1.71)$ \\
\hline & Good & 82 & 108 & $0.54(0.40 ; 0.73)$ & $1.01(0.62 ; 1.66)$ \\
\hline & Excellent & 26 & 46 & $0.45(0.30 ; 0.67)$ & $0.98(0.52 ; 1.85)$ \\
\hline \multirow{4}{*}{ Satisfaction with the grades ${ }^{*}$} & Insufficient & 34 & 15 & 1 & 1 \\
\hline & Regular & 57 & 68 & $0.66(0.50 ; 0.86)$ & $0.81(0.58 ; 1.11)$ \\
\hline & Good & 62 & 91 & $0.58(0.45 ; 0.76)$ & $0.76(0.52 ; 1.10)$ \\
\hline & Excellent & 11 & 22 & $0.48(0.29 ; 0.81)$ & $1.10(0.58 ; 2.08)$ \\
\hline \multirow{4}{*}{ Academic perform* } & Insuficient & 10 & 3 & 1 & 1 \\
\hline & Regular & 50 & 59 & $0.60(0.41 ; 0.85)$ & $0.81(0.53 ; 1.23)$ \\
\hline & Good & 95 & 115 & $0.59(0.42 ; 0.82)$ & $0.92(0.58 ; 1.44)$ \\
\hline & Excellent & 9 & 19 & $0.42(0.22 ; 0.77)$ & $0.66(0.30 ; 1.44)$ \\
\hline
\end{tabular}

* Variable eliminated in your hierarchical level.

Meta-analysis research with Brazilian medical students identified a CMD prevalence of $31.5 \% .^{15}$ However, it is observed differences in CMD prevalence among the universities. Some presented prevalence more significant than the one observed in the meta-analysis, such as universities located in São Paulo $(44.7 \%),{ }^{2}$ in Sergipe $(40.0 \%)^{16}$ and Southeast Bahia (32.2\%). ${ }^{17}$

These differences founded can be attributed to social, cultural and environmental factors, as well as due to the different instruments used to identify the mental disorders among students. Besides, this result can be because of the real difference.

The CMD prevalence in this study was higher among female students when compared to males. This finding is similar to studies performed in Saudi Arabia, ${ }^{18}$ Ethiopia, ${ }^{7}$ Malaysia ${ }^{19}$ and Brazil. ${ }^{15,20-22}$ However, some studies did not find sex differences in CMD prevalence. ${ }^{1,2,16}$ The way women face social, economic and environmental situations is different from men, which is why women are more subject to developing mental disorders. ${ }^{23}$

Although the present study did not find an association between the years of study and CMD, another research performed in Brazil identified that students in more advanced semesters are more likely to have CMD than the ones in the initial years. ${ }^{16}$ However, a study performed in Ethiopia also did not find an association between years of study and CMD. ${ }^{7}$ This can be explained by the fact that the participants in 
this study learn through the PBL method, and the prevalence of psychic suffering is lower in students who learn through PBL when compared to the students learning through traditional method. ${ }^{24}$ Possibly, this can be attributed to the fact that the student participates actively in the knowledge search through tutorial sessions, practical classes and public health unities medical services follow-up since the beginning of their course, which raises their motivation and security concerning the learning content.

The unsatisfactory sleep quality was another factor that presented association to CMD between the participants of this study. The extensive educational content, the constant pressure and the stress lived by the students during the entire course, added to the lack of time for leisure and few hours of sleep per night, generate feelings of anguish and anxiety. ${ }^{15,22,24}$ Sleep perturbations may produce significant individual alterations in physical functioning ${ }^{25}$ occupational, cognitive and social, besides compromise substantially the students' quality of life. ${ }^{25}$

Besides, the fear with their academic performance, the desire to give up the course and the physical discomfort during the exams were some other factors associated with CMD in this study. The poor academic performance and the desire to give up the course were risk factors also found in Botucatu University medical students. ${ }^{2}$ In Belgrade, the CMD risk was among students who presented stress during the exam ${ }^{26}$ and, in Sergipe, among the students who do not feel well, happy and satisfied with their course. ${ }^{16}$ The fear was another factor very present in the medical student. Many times, the need to talk to the professor to clarify some doubts was a stressing factor for the student. ${ }^{1,26}$

The emotional support, mainly by friends, is essential for reducing CMD among medical students. This study observed that the students that felt rejected by their friends presented a higher risk to CMD. This finding coincides with other studies performed in Brazil ${ }^{1,2,15}$ and Ethiopia. ${ }^{7}$

Although the relatives' mental health is another factor that will influence CMD risk, this study found a higher CMD risk among students who had relatives with mental disorders and this finding is the following study performed in Ethiopia. ${ }^{7}$ This can be explained by the genetic predisposition and familiar conditions since the presence of a familiar with CMD raises the risk for stress. ${ }^{23}$

This study presents some significant limitations that can influence in results' interpretation. First, a transversal study cannot establish a cause-effect relation. However, this problem was minimized by excluding from the research the students who did or were still doing psychological and/or psychiatric treatment. Besides, the study presented a selection bias due to free assent by the student to the research, which can cause differences in the found prevalence, but not in the association. Another bias that can be present is the information bias since the data were collected by self-referred information; however, this bias is reduced when the information is collected secretively. Lastly, it is necessary to consider that the SRQ-20 track CMD suspected cases, being the psychiatrist interview the gold standard for diagnosis.

\section{Conclusion}

The CMD general prevalence among the students was high and more prevalent in women. The existence of a familiar with CMD, the friends' rejection, the fear compromising the academic performance, the poor sleep quality, the physical discomfort during the exams and even the desire to give up the course 
were CMD associated factors. Therefore, it is recommended that educational institutions, governmental agencies and the families be alert to this problem that affects the medical students. Programs destined to reduce the medical student mental suffering need to be implanted to identify the risk factors and to take action with measures to reduce this alarming scenario.

\section{Acknowledgments}

The authors acknowledge Vila Velha University for the financial support thought scientific initiation scholarships for the students' participants on this study and for the logistic support to perform the data collection with the enrolled medical school students in the institution.

\section{Author's contribution}

Conception and/or design of the study: ASSGM, FACV, ARMS, WLP. Data gathering, analysis or interpretation: ASSGM, FACV, ARMS, WLP. Preliminary draft: ASSGM, FACV, ARMS, WLP. Critical review of the preliminary draft: ASSGM, FACV, ARMS, WLP. All the authors have approved the final version and agreed to be accountable for all aspects of the work

\section{Conflict of interest}

None declared.

\section{References}

1. Fiorotti KP, Rossoni RR, Borges LH, Miranda AE. Transtornos mentais comuns entre os estudantes do curso de medicina: prevalência e fatores associados. J Bras Psiquiatr. 2010;59(1):17-23. https://doi.org/10.1590/S0047-20852010000100003

2. Lima MCP, Domingues MS, Cerqueira ATAR. Prevalência e fatores de risco para transtornos mentais comuns entre estudantes de medicina. Rev Saúde Pública. 2006;40(6):1035-41. https://doi.org/10.1590/S0034-89102006000700011

3. Pagnin D, de Queiroz V. Comparison of quality of life between medical students and young general populations. Educ Health (Abingdon). 2015;28(3):209-12. https://doi.org/10.4103/1357-6283.178599

4. Rocha ES, Sassi AP. Transtornos mentais menores entre estudantes de medicina. Rev Bras Educ Med. 2013;37(2):210-6. https://doi.org/10.1590/S0100-55022013000200008

5. Vidal CEL, Amara B, Ferreira DP, Dias IMF, Vilela LA, Franco LR. Preditores de prováveis transtornos mentais comuns (TMC) em prostitutas utilizando o Self-Reporting Questionnaire. J Bras Psiquiatr. 2014;63(3):205-12. https://doi.org/10.1590/00472085000000027

6. Malhotra S, Shah R. Women and mental health in India: An overview. Indian J Psychiatry. 2015;57(Suppl 2):S205-11. https://doi.org/10.4103/0019-5545.161479

7. Dachew BA, Azale Bisetegn T, Berhe Gebremariam R. Prevalence of mental distress and associated factors among undergraduate students of University of Gondar, Northwest Ethiopia: a cross-sectional institutional based study. PLoS One. 2015;10(3):e0119464. https://doi.org/10.1371/journal.pone.0119464

8. Ferreira CMG, Kluthcovsky ACGC, Cordeiro TMG. Prevalência de Transtornos Mentais Comuns e Fatores Associados em Estudantes de Medicina: um Estudo Comparativo. Rev Bras Educ Med. 2016;40(2):268-77. https://doi.org/10.1590/1981$52712015 \mathrm{v} 40 \mathrm{n} 2 \mathrm{e} 02812014$

9. Organização Mundial da Saúde (OMS). Relatório Mundial da Saúde. Saúde Mental: Nova concepção, nova esperança. Lisboa: OMS/ Direcção-Geral da Saúde; 2002.

10.10. Santos KOB, Araújo TM, Pinho OS, Silva ACC. Avaliação de um instrumento de mensuração de morbidade psíquica: estudo de validação do Self-reporting Questionnaire (SRQ-20). Rev Baiana Saúde Pública. 2010;34(3):544-60. https://doi.org/10.22278/23182660.2010. v34.n3.a54 
11. Mari JJ, Williams P. A comparison of the validity of two psychiatric screening questionnaires (GHQ-12 and SRQ-20) in Brazil, using Relative Operating Characteristic (ROC) analysis. Psychol Med. 1985;15(3):651-9. https://doi.org/10.1017/S0033291700031500

12. Borst JM, Frings-Dresen MHW, Sluiter JK. Prevalence and incidence of mental health problems among Dutch medical students and the study-related and personal risk factors: a longitudinal study. Int J Adolesc Med Health. 2016;28(4):349-55. https://doi.org/10.1515/ ijamh-2015-0021

13. Bernhardsdóttir J, Vilhjálmsson R. Psychological distress among university female students and their need for mental health services. J Psychiatr Ment Health Nurs. 2013;20(8):672-8. https://doi.org/10.1111/jpm.12002

14. Stallman HM. Psychological distress in university students: A comparison with general population data. Aust Psychol Soc. 2010;45(45):249-57. https://doi.org/10.1080/00050067.2010.482109

15. Pacheco JP, Giacomin HT, Tam WW, Ribeiro TB, Arab C, Bezerra IM, et al. Mental health problems among medical students in Brazil: a systematic review and meta-analysis. Rev Bras Psiquiatr. 2017;39(4):369-78. https://doi.org/10.1590/1516-4446-2017-2223

16. Costa EFO, Andrade TM, Silvany Neto AM, Melo EV, Rosa ACA, Alencar MA, et al. Common mental disorders among medical students at Universidade Federal de Sergipe: a cross-sectional study. Rev Bras Psiquiatr. 2010;32(1):11-9. https://doi.org/10.1590/S151644462010000100005

17. Santos LS, Ribeiro IJS, Boery EN, Boery RNSO. Qualidade de Vida e Transtornos Mentais Comuns em Estudantes de Medicina. Cogitare Enferm. 2017;22(4):e52126. https://doi.org/10.5380/ce.v22i4.52126

18. Abdulghani HM, AlKanhal AA, Mahmoud ES, Ponnamperuma GG, Alfaris EA. Stress and its effects on medical students: a crosssectional

19. study at a college of medicine in Saudi Arabia. J Health Popul Nutr. 2011;29(5):516-22. https://doi.org/10.3329/jhpn.v29i5.8906

20. Maher DFF, Munn SL, Normala I, Siti IFBI, Phang CK. Prevalence and risk factors of Stress, Anxiety and Depression among Preclinical Medical students in Universiti Putra Malaysia in 2014. Int J Collab Res Intern Med Public Health. 2015;7(1):1-12.

21. Jansen K, Mondin TC, Ores LC, Souza LDM, Konradt CE, Pinheiro RT, Silva RA. Transtornos mentais comuns e qualidade de vida em jovens: uma amostra populacional de Pelotas, Rio Grande do Sul, Brasil. Cad Saúde Pública. 2011;27(3):440-8. https://doi.org/10.1590/ S0102-311X2011000300005

22. Abrão CB, Coelho EP, Passos LBS. Prevalência de sintomas depressivos entre estudantes de medicina da Universidade Federal de Uberlândia. Rev Bras Educ Med. 2008;32(3):315-23. https://doi.org/10.1590/S0100-55022008000300006

23. Almeida AM, Godinho TM, Bitencourt AGV, Teles MS, Silva AS, Fonseca DC, et al. Common mental disorders among medical students. J Bras Psiquiatr. 2007;56(4):245-51. https://doi.org/10.1590/S0047-20852007000400002

24. World Health Organization (WHO). WHO and the Calouste Gulbenkian Foundation: Social determinants of mental health. Geneva:WHO; 2014.

25. Tenório LP, Argolo VA, Sá HP, Melo EV, Costa EFO. Saúde Mental de Estudantes de Escolas Médicas com Diferentes Modelos de Ensino. Rev Bras Educ Med. 2016 40(4):574-82. https://doi.org/10.1590/1981-52712015v40n4e00192015

26. Müller MR, Guimarães SS. Impacto dos transtornos do sono sobre o funcionamento diário e a qualidade de vida. Estud Psicol (Campinas). 2007;24(4):519-28. https://doi.org/10.1590/S0103-166X2007000400011

27. Backović DV, Maksimović M, Davidović D, Zivojinović JI, Stevanović D. Stress and mental health among medical students. Srp Arh Celok Lek. 2013;141(11-12):780-4. https://doi.org/10.2298/SARH1312780B 